\title{
Abundance and conservation status of two newly described lemur species in northwestern Madagascar (Microcebus danfossi, Lepilemur grewcockorum)
}

\author{
Blanchard Randrianambinina', Solofonirina \\ Rasoloharijaona', Romule Rakotondravony', \\ Elke Zimmermann" and Ute Radespiel"
}

\author{
Correspondence: \\ Ute Radespiel \\ Institute of Zoology, University of Veterinary Medicine Hannover \\ Buenteweg 17, 30559 Hannover, Germany, \\ E-mail: Ute.Radespiel@tiho-hannover.de
}

\begin{abstract}
The distribution and abundance of Danfoss' mouse lemurs (Microcebus danfossi) and Grewcock's sportive lemurs (Lepilemur grewcockorum), two regional endemics from northwestern Madagascar, were studied from May to December 2008 in the Sofia region between the rivers Sofia and Maevarano. The goal was to investigate the size and quality of forest fragments and to determine the presence and abundance of the recently described $M$. danfossi and L. grewcockorum. They are confined to this region and their conservation status has not yet been determined. A total of eleven sites were visited and systematic census observations were carried out in each of them. $M$. danfossi was present in ten of eleven sites and its abundance ranged from 4.5 to 8.5 individuals per kilometer. L. grewcockorum was present in only three of eleven sites and its abundance ranged from 0.8 to one individual per kilometre. Based on the results of this study $M$. danfossi should be listed as Vulnerable and L. grewcockorum as Endangered. Based on the abundance data, the size and the general condition of the fragments, the forests of Anjajavy, Ambarijeby and Bekofafa are most favorable for future protection, because they still contain the most intact nocturnal lemur communities.
\end{abstract}

\section{RÉSUMÉ}

Une étude sur la distribution et l'abondance de Microcebus danfossi et Lepilemur grewcockorum, deux espèces endémiques de la région Nord-ouest de Madagascar, a été effectuée dans la région de Sofia, entre les fleuves Sofia et Maevarano, de mai à décembre 2008. Les objectifs étaient d'évaluer la qualité et la largeur des fragments forestiers restants ainsi que de déterminer la diversité de lémuriens nocturnes dans la région. Nous avons aussi prévu de détecter des sites potentiels en vue de la conservation de fragments présentant une biodiversité riche, en particulier en ce qui concerne les espèces de lémuriens nocturnes récemment décrites dans cette région, $M$. danfossi et L. grewcockorum. Enfin, nous avons récolté toutes les informations disponibles afin de proposer une classification objective pour chaque espèce conformément aux critères de I'IUCN. Nous avons inventorié onze sites au total, à savoir la forêt d'Anjajavy, le savoka du village d'Antonibe, la forêt d'Antambato, le savoka d'Antsatrana, la forêt de Beanamalao, la forêt de Betsatsika, la forêt d'Ambarijeby, la forêt d'Ankaramikely, la forêt de Bekofafa, les savoka d'Ambararata et de Mahadera. Dans chaque site de ces sites, nous avons évalué la qualité de la forêt (signe de feu, déboisement, trouées) et la surface du fragment avant de réaliser six inventaires nocturnes le long de deux pistes de $1 \mathrm{~km}$ de longueur. Nous avons identifié de deux à quatre espèces de lémuriens nocturnes par site et au total cinq espèces ont été recensées. $M$. danfossi était présent dans dix sites et son abondance variait de 4,5 à 8,5 individus par kilomètre. L. grewcockorum n'était présent que dans trois sites et son abondance variait de 0,8 à 1,0 individu par kilomètre. Les fragments avaient des superficies comprises entre 50 et 400 ha. Les forêts d'Anjajavy, d'Ankaramikely, d'Antambato et de Bekofafa se sont avérées être les meilleurs sites en matière de qualité de la forêt. Compte tenu du degré de fragmentation, des pressions anthropiques et de nos résultats d'inventaire de ces deux espèces endémiques, nous proposons un statut de conservation Vulnérable pour $M$. danfossi et En Danger pour L. grewcockorum. Nous proposons également de considérer la protection des forêts d'Anjajavy, d'Ambarijeby et de Bekofafa dans la mesure où elles sont encore intactes et abritent un assez grand nombre d'espèces de lémuriens.

KEYWORDS: Mouse lemur, distribution, fragmentation, primates, sportive lemur.

MOTS CLEFS : microcèbe, distribution, fragmentation, primates, lépilémur.

\section{INTRODUCTION}

Madagascar is considered one of the biodiversity hotspot countries due to its unique wildlife and to high levels of anthropogenic pressure on the island. Therefore, it is at the top of conservation priority lists worldwide (Myers et al. 2000). Lemurs are 100\% endemic to Madagascar and with more than 95 extant species (Mittermeier et al. 2010), they represent the largest of only five extant mammalian orders present on the island. Lemurs are forest dependent and therefore particularly threatened by the 
dramatic degree of deforestation and habitat degradation on the island (Harper et al. 2007, Kremen et al. 2008). On the other hand, we still lack important datasets on the biology and distribution of many species, in particular on the nocturnal, cryptic taxa. This makes it extremely difficult to estimate their exact threat level and to formulate effective conservation strategies. More specifically, 42 of 92 lemur taxa $(45.7 \%)$, presently listed in the IUCN Red List (<WwW.redlist.org >), are categorized as 'data deficient' This study aims to determine the conservation status of two of these species that belong to the lemur genera with the highest species richness, the nocturnal mouse lemurs (Microcebus spp.) and sportive lemurs (Lepilemur spp.).

Mouse lemurs are the smallest primates in the world. In early studies, only two species, Microcebus murinus and M. rufus, were described distinguished (Martin 1972). However the diversity within the genus Microcebus is currently judged to be much higher (Mittermeier et al. 2008, Weisrock et al. 2010) Recent molecular, genetic, acoustic and morphological studies have resulted in an extraordinary increase in the number of recognized species with 16 further species having been described or resurrected within the last 16 years (Schmid and Kappeler 1994, Zimmermann et al. 1998, Rasoloarison et al. 2000, Yoder et al. 2000, Andriantompohavana et al. 2006, Louis et al. 2006a, Olivieri et al. 2007, Louis et al. 2008, Radespiel et al. 2008) However, we still lack information on the biology and distribution of most species which prevents a full evaluation of their conservation status.

Sportive lemurs (Lepilemur spp.) live in almost all remaining forest regions of Madagascar (Harcourt and Thornback 1990, Mittermeier et al. 2003). The species diversity within this genus as well as their distribution and conservation status is only poorly known (Mittermeier et al. 2003). Recent molecular taxonomic studies have shown that the species diversity in Lepilemur was also highly underestimated and the number of described species has increased to 25 over the years (Andriaholinirina et al. 2006, Louis et al. 2006b, Rabarivola et al. 2006, Craul et al. 2007, Lei et al. 2008).

Until recently, the mouse lemurs and the sportive lemurs of the Antsohihy region (area about $11,000 \mathrm{~km}^{2}$ between the rivers Sofia and Maevarano) have been assigned to their close relatives and geographic neighbours to the south: Microcebus ravelobensis and Lepilemur edwardsi, respectively. In 2006 and 2007, however, two new nocturnal lemur species were described from this region, $M$. danfossi and L. grewcockorum (Louis et al. 2006a, Olivieri et al. 2007). They differ from their neighbouring congeners in 2-5 (L. grewcockorum) and 2-10 (M. danfossi) morphometric measurements (Craul et al. 2007, Olivieri et al. 2007). Furthermore, they have unique molecular diagnostic sites in the sequenced mitochondrial loci and have already clearly diverged on the molecular level from their geographic neighbours during their isolated evolutionary history (Louis et al. 2006b, Craul et al. 2007, Olivieri et al. 2007). Due to their very recent description, information on their distribution and abundance in northwestern Madagascar is still lacking. The forests in this region typically consist of relatively small forest fragments $\left(1.5-37 \mathrm{~km}^{2}\right.$, Olivieri et al. 2008), which are disturbed by human activities such as illicit timber exploitation and/or poaching. Due to their very small geographic range and the rate of ongoing habitat loss and fragmentation in the area, it is critical to determine the distri- bution and abundance of the remaining populations. For this purpose, we collected data on the distribution and abundance of both newly described lemur species and on the presence of other nocturnal lemur species at eleven different locations in northwestern Madagascar. In addition, we estimated the amount of anthropogenic disturbance at each site in order to determine the actual conservation status of $M$. danfossi and L. grewcockorum and to develop recommendations for the future conservation of these two regional endemics.

\section{METHODS}

LOCALIZATION AND SELECTION OF STUDY SITES.

Previous studies have suggested that the Sofia River and the Maevarano River limit the global distribution of both lemur species to the north and south, respectively (Olivieri et al. 2007, Craul et al. 2007). The field study was therefore conducted in 2008 at eleven sites between these two rivers. The sites varied in altitude from almost sea level (site 1) in the west to more than 1,700 m altitude (site 3) in the east (see Figure 1, Table 1). Study sites were chosen based on a combination of forest cover information from satellite imagery (Landsat, Google Earth). We aimed to visit large fragments, whenever possible, since our priority was to identify promising candidate forests for future conservation efforts.

ANTHROPOGENIC DISTURBANCE IN THE FOREST.

Forest fragments were surveyed along two transects per site: Signs of anthropogenic disturbance were recorded as the amount of cut wood, traces of fire, and numbers of holes in the ground from extracting tubers. Anthropogenic disturbance was noted every $40 \mathrm{~m}$ within a $10 \mathrm{~m}$ radius along two $1 \mathrm{~km}$ trails where the census counts were also conducted. We used pre-existing trails for this study in order to avoid any study-induced habitat disturbances. Transect trails were straight and representative of the habitat. The degree of disturbance was expressed as the percentage of trail points showing disturbances. We calculated separately the average of all disturbances on each trail and then determined the average for two trails. Anthropogenic disturbance was considered 'low', if the percentage of affected points ranged between zero and $30 \%$ (good condition), 'average' if ranging between 30 and $60 \%$ (average condition) and 'strong' if greater than $60 \%$ (bad condition). In addition, we walked along the border of the forest and took the GPS co-ordinates in order to estimate the size of the forest fragment either in the field or retrospectively with the help of satellite imagery.

CENSUS OBSERVATIONS. TwO observers conducted

one census per night together for three nights along each trail. The census observations were performed along a $1 \mathrm{~km}$ transect line, and began at about 1800h and lasted approximately 2 hours. During a census, both observers moved slowly to detect all the animals close to the transect line. One observer focused to the right side of the trail, the second to the left. Head lamps were used to locate the animals by their eye shine. Once an animal was visually detected, one observer noted all the parameters and the second followed the individual and identified the species using a strong flash light. Nocturnal species and genera were discriminated based on their overall size (sufficient for discrimination between Microcebus sp., Cheirogaleus sp., and Lepilemur sp./Avahi sp.) and their head proportions (relative ear size and protrusion of snout differs between Lepilemur sp. and Avahi sp.). Each detection was recorded on a dictaphone 


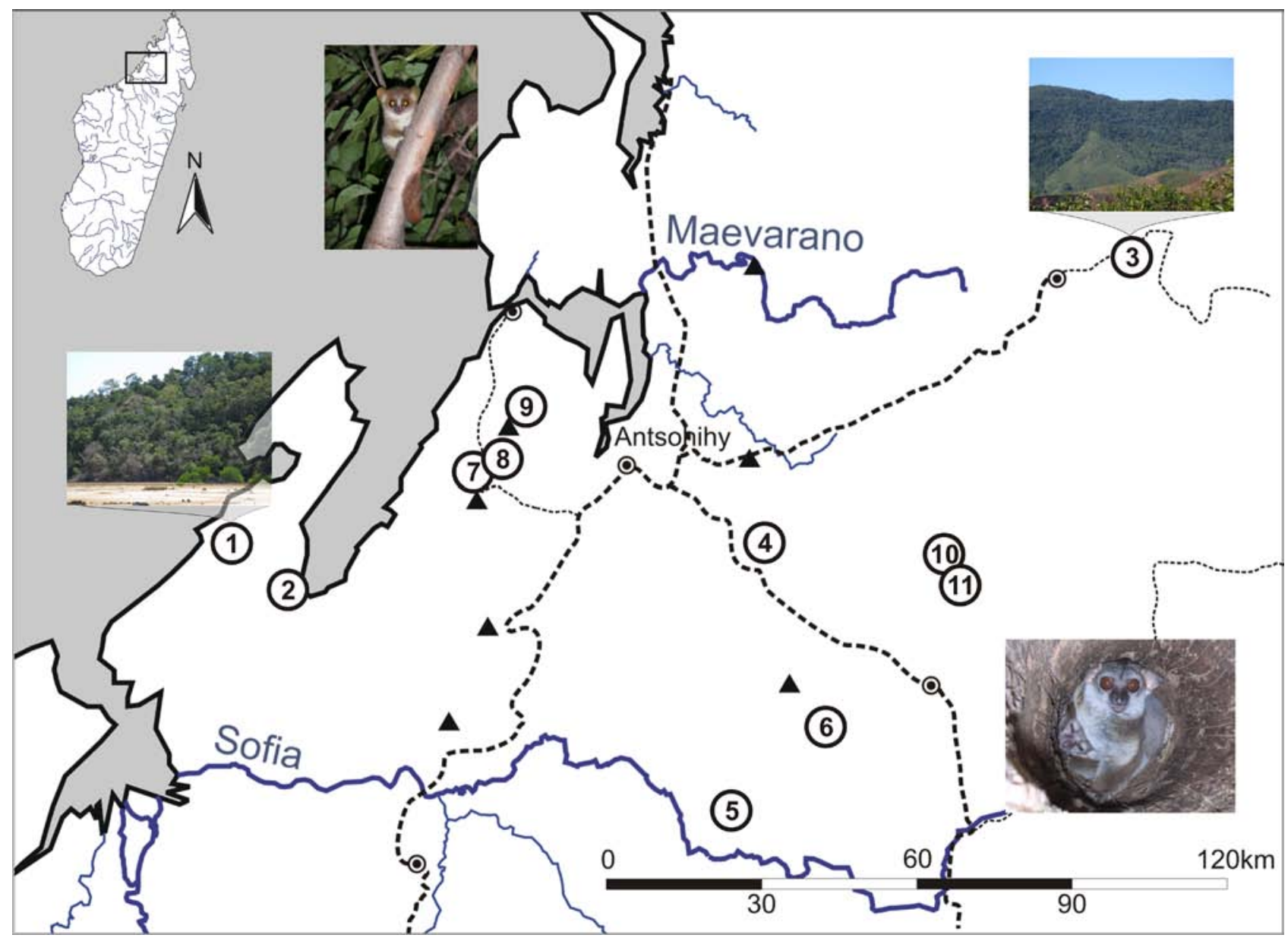

FIGURE 1. Map of northwestern Madagascar showing our study sites (numbered from 1-11) and the study sites of a previous study (Olivieri et al. 2005, black triangles), larger towns (black \& white dots) and main roads (dashed lines) between the two rivers Sofia and Maevarano. The photos depict the easternmost (site 3, Antambato) and the westernmost (site 1, Anjajavy) site and the two regional endemics under study (Microcebus danfossi - left-upper corner, Lepilemur grewcockorum - right-lower corner). Photos were taken by B.R. (landscapes and M. danfossi) and by M. Craul (L. grewcockorum).

and the following parameters were noted: (i) direct distance between the observer and the animal, (ii) perpendicular distance between the animal and the trail, and (iii) the angle between the animal, the observer, and the trail.

ESTIMATION OF LEMUR ABUNDANCE. The composition of the nocturnal lemur communities at the study sites was obtained from the nocturnal census observations. The encounter rate, i.e. the number of individuals of Microcebus danfossi and Lepilemur grewcockorum observed per kilometer of census observation was determined for each census walk. Population densities could be estimated for Microcebus spp. only due to limited encounter frequencies for the other nocturnal species. Population densities of Microcebus spp. ( $/$ / A) were estimated based on the census data by using the formula given by Müller et al. (2000): $\tilde{N} / A=\tilde{n} /(2 \times \mid \times W)$

- $\tilde{N}$ : Number of individuals in the zone of census,

- A: Area of the zone of census,

- $\tilde{n}$ : Average of the numbers of the individuals within $w$,

- $w$ : Width of the field of detection on each side of the transect,

- I: Length of the transect.

All animals detected outside $w$ were excluded (Müller et al. 2000); w was determined using histograms with distance classes, effectively partitioning all sightings of Microcebus spp. according to their perpendicular distances. The width
$W$ is defined as the distance where the number of detected individuals decreases by $1 / 3$ or more compared to the preceding distance class. This upper limit of the distance class is the so-called 'fall-of-distance'. The width of detection is considered the same for both sides of the trail.

STATISTICAL ANALYSES. The relationship between fragment

size and the level of anthropogenic disturbances was tested with an ANOVA (Type VI, sigma restricted). The relationships between the number of nocturnal lemur species, the

TABLE 1. Geographical coordinates, altitude, and survey month of the study sites.

\begin{tabular}{|c|c|c|c|c|}
\hline $\begin{array}{l}\text { Site } \\
\text { no. }\end{array}$ & Site & Coordinates & Altitude & Month \\
\hline 1 & Anjajavy & S1501'39.6" E47¹6'38.4" & $25 \mathrm{~m}$ & May \\
\hline 2 & Antonibe & $\mathrm{S} 15^{\circ} 06^{\prime} 14.6^{\prime \prime} \mathrm{E} 47^{\circ} 22^{\prime} 42.1^{\prime \prime}$ & $44 \mathrm{~m}$ & May \\
\hline 3 & Antambato & S1430'38.3" E4852'41.1" & 1759 m & May \\
\hline 4 & Andranotsara & $\mathrm{S} 15^{\circ} 00^{\prime} 49.8^{\prime \prime} \mathrm{E} 48^{\circ} 13^{\prime} 55.8^{\prime \prime}$ & $178 \mathrm{~m}$ & June \\
\hline 5 & Beanamalao & $\mathrm{S} 15^{\circ} 28^{\prime} 45.7^{\prime \prime} \quad \mathrm{E} 48^{\circ} 10^{\prime} 44.4^{\prime \prime}$ & $227 \mathrm{~m}$ & June \\
\hline 6 & Betsatsika & S1519'53.3" E48²0'45.2" & $294 \mathrm{~m}$ & June \\
\hline 7 & Ambarijeby & S1453'20.9" E4743'17.8" & $147 \mathrm{~m}$ & July \\
\hline 8 & Bekofafa & 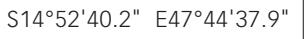 & $143 \mathrm{~m}$ & August \\
\hline 9 & Ankaramikely & $\mathrm{S} 14^{\circ} 46^{\prime} 50.5^{\prime \prime} \mathrm{E} 47^{\circ} 47^{\prime} 52.3^{\prime \prime}$ & $199 \mathrm{~m}$ & August \\
\hline 10 & Ambararata & S1504'05.3" E48³4'11.2" & $780 \mathrm{~m}$ & December \\
\hline 11 & Mahadera & $\mathrm{S} 15^{\circ} 02^{\prime} 24.4^{\prime \prime} \mathrm{E} 48^{\circ} 33^{\prime} 33.8^{\prime \prime}$ & $366 \mathrm{~m}$ & December \\
\hline
\end{tabular}


encounter frequencies of mouse lemurs, their population densities and fragment size was tested by using a simple regression analysis (Type VI, all effects). Finally, the influence of the anthropogenic disturbances on the number of nocturnal lemur species, the encounter frequencies and population densities of mouse lemurs was also tested with an ANOVA (Type $\mathrm{VI}$, sigma restricted). All statistical analyses were conducted with STATISTICA 6.0.

\section{RESULTS}

A total of six nocturnal lemur species were found during the survey including Microcebus danfossi, Microcebus mittermeieri, Cheirogaleus medius, Lepilemur grewcockorum and Avahi sp. Traces of aye-aye tooth gnawings on numerous dead tree trunks, traces of nests, and independent interviews with local villagers also suggested the occurrence of Daubentonia madagascariensis in some sites (Table 2). The number of nocturnal lemur species in a given site ranged between two and four. Whereas Microcebus spp. and C. medius were present in all sites, the three larger species were absent from six (D. madagascariensis), eight (L. grewcockorum) and ten (Avahi sp.) sites. The highest number of species was found in Anjajavy, Ambarijeby and Bekofafa. Fragments of different levels of disturbance differed as a statistical trend with regard to the number of nocturnal lemur species that were found $(F(2,8)=3.5421, p=0.079)$. Fragments of disturbance level 3 tended to host fewer lemur species than fragments with lower levels of disturbance (Figure 2-a1).

Microcebus danfossi was found in ten sites up to a maximum altitude of $780 \mathrm{~m}$ a.s.l. (site 10, confirmed by molecular data, Radespiel unpubl. data). Site 3 (Antambato) contained M. mittermeieri, which was also confirmed by molecular data (Radespiel unpubl. data). The abundance of Microcebus spp. along the census trails ranged from 4.5 to 8.5 individuals per kilometre with the highest values in Anjajavy, Antonibe and Beanamalao. The population density estimates of $M$. danfossi varied from 2.2 to 5.0 individuals per hectare with the highest values being estimated for Antonibe, Beanamalao, Ambarijeby and Mahadera (Table 3). Lepilemur grewcockorum was found in three sites only (Anjajavy, Ambarijeby and Bekofafa). If present, their abundance along the census trails ranged from 0.8 to 1.0 individual per kilometre. Sportive lemurs were detected at a mean perpendicular distance of $2.9 \mathrm{~m}(n=4$, site 8) and $11.6 \mathrm{~m}$

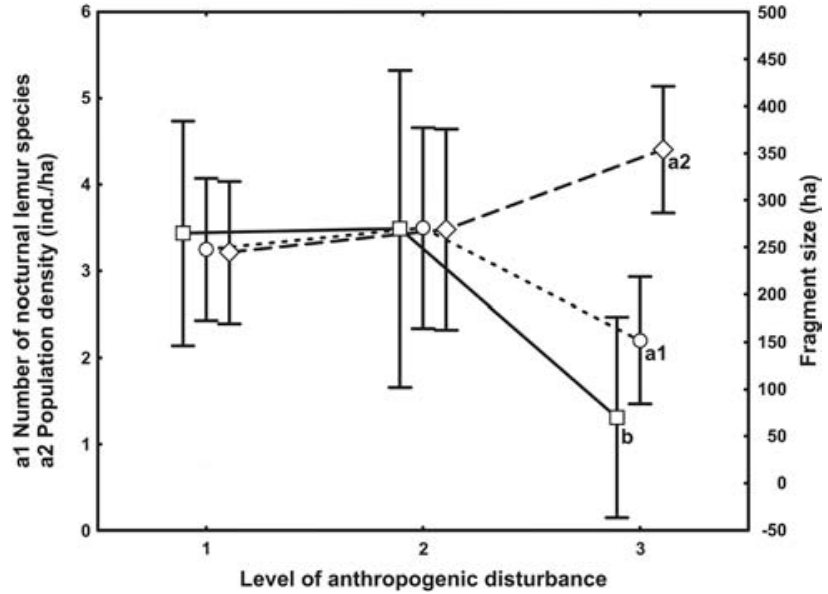

FIGURE 2. a) Effect of the level of disturbance on (a1) the number of nocturnal lemur species that were present in the forest fragments (circles with dotted line), (a2) the population densities of mouse lemurs (diamonds with dashed line), and (b) differences in fragment size between sites of different levels of disturbance (squares with continuous line). Means and $95 \%$ confidence intervals (error bars) are shown.

( $n=5$, site 1) from the trail. Fragment sizes varied from 50 to 400 ha. The sites of Anjajavy and Beanamalao were the largest forests followed by Ankaramikely. With regard to the degree of anthropogenic disturbances, the sites Anjajavy, Ankaramikely, Antambato, and Bekofafa were in the best condition of all visited sites (Table 3). Not surprisingly, the ANOVA revealed that fragments of the three different degrees of disturbance differed in size $(F(2,8)=4.9714, p=0.03952$, Figure $2 b)$. Fragments with the highest level of disturbance were significantly smaller (meand3 \pm SD: $70 \pm 40$ ha) than fragments of a lower level of disturbance (meand \pm SD: $265 \pm 52$ ha, meand \pm SD: $270 \pm$ 73 ha). A regression analysis, however, revealed no significant relationship between fragment size and encounter frequency $\left(R^{2}=0.070, F(1,9)=0.67958\right.$, n.s. $)$ or population density $\left(R^{2}=0.037, F(1,9)=0.34640\right.$, n.s. $)$ of mouse lemurs. Fragments of different levels of disturbance also did not differ significantly in encounter frequencies (ANOVA, $F(2,8)=0.28833$, n.s.), but differed as a statistical trend with regard to population densities (ANOVA, $F(2,8)=3.3612, p=0.087$ ). Interestingly, population densities of mouse lemurs tended to be higher in fragments with a higher level of disturbance (Figure 2-a2). In contrast L. grewcockorum was never found in fragments of the highest level of disturbance (level 3, Table 3).

TABLE 2. Presence/absence of nocturnal lemur species in the eleven study sites. + : Species observed during census observations, 1 : by interviews with local guides, 2: presence of trace of nest.

\begin{tabular}{|c|c|c|c|c|c|c|c|}
\hline Site no. & Site & $\begin{array}{c}\text { Microcebus } \\
\text { danfossi }\end{array}$ & M. mittermeieri & $\begin{array}{c}\text { Cheirogaleus } \\
\text { medius }\end{array}$ & $\begin{array}{l}\text { Lepilemur } \\
\text { grewcockorum }\end{array}$ & Avahi sp. & $\begin{array}{c}\text { Daubentonia } \\
\text { madagascariensis }\end{array}$ \\
\hline 1 & Anjajavy & + & & 1 & + & & 1 \\
\hline 2 & Antonibe & + & & 1 & & & \\
\hline 3 & Antambato & & + & 1 & & + & \\
\hline 4 & Andranotsara & + & & 1 & & & 1.2 \\
\hline 5 & Beanamalao & + & & 1 & & & 1 \\
\hline 6 & Betsatsika & + & & 1 & & & \\
\hline 7 & Ambarijeby & + & & + & + & & 2 \\
\hline 8 & Bekofafa & + & & 1 & + & & 1 \\
\hline 9 & Ankaramikely & + & & 1 & & & \\
\hline 10 & Ambararata & + & & 1 & & & \\
\hline 11 & Mahadera & + & & 1 & & & \\
\hline
\end{tabular}


TABLE 3. Characterization of the study sites, encounter frequency and population density of Microcebus danfossi, and encounter frequency of Lepilemur grewcockorum at each site.

\begin{tabular}{|c|c|c|c|c|c|}
\hline Sites & $\begin{array}{l}\text { Estimated area of } \\
\text { the forest (ha) }\end{array}$ & $\begin{array}{l}\text { Overall state of the forest } \\
\text { (1: good, } 2 \text { : average, } 3 \text { : bad) }\end{array}$ & $\begin{array}{l}\text { Encounter frequency of } \\
\begin{array}{c}\text { Microcebus spp. } \\
\pm \mathrm{SD} / \mathrm{km}\end{array}\end{array}$ & $\begin{array}{c}\text { Encounter frequency of } \\
\begin{array}{c}\text { L. grewcockorum } \\
\pm S D / k m\end{array}\end{array}$ & $\begin{array}{l}\text { Population density (ind/ha) } \\
\text { of Microcebus spp. }\end{array}$ \\
\hline Anjavavy & 400 & 1 & $8.5 \pm 4.2$ & $0.8 \pm 0.5$ & 3.7 \\
\hline Antonibe & 50 & 3 & $8.0 \pm 0.0$ & & 5.0 \\
\hline Antambato & 150 & 1 & $4.8 \pm 3.9$ & & 2.2 \\
\hline Andranotsara & 100 & 3 & $6.8 \pm 0.4$ & & 4.1 \\
\hline Beanamalao & 400 & 2 & $8.0 \pm 2.8$ & & 4.3 \\
\hline Betsatsika & 70 & 3 & $5.8 \pm 1.8$ & & 4.6 \\
\hline Ambarijeby & 140 & 2 & $4.7 \pm 1.9$ & + & 2.7 \\
\hline Bekofafa & 160 & 1 & $6.5 \pm 5.0$ & $1 \pm 0.8$ & 3.4 \\
\hline Ankaramikely & 350 & 1 & $6.0 \pm 0.7$ & & 3.6 \\
\hline Ambararata & 70 & 3 & $7.0 \pm 0.7$ & & 3.5 \\
\hline Mahadera & 60 & 3 & $7.8 \pm 0.2$ & & 4.8 \\
\hline
\end{tabular}

\section{DISCUSSION}

The eleven study sites were very different in forest size and in their diversity of nocturnal lemurs. In general, the results were similar to those of a previous study by Olivieri et al. (2005), except that we could never confirm the presence of Mirza sp. or Phaner sp. in our study. In contrast, we found Microcebus spp. and Cheirogaleus medius in all sites. These genera seem to be able to live in degraded and/or small forests independent of the variation in forest size and the level of disturbance. Interestingly, population densities of mouse lemurs were even higher in sites with high levels of disturbance. Since this effect was not seen in the encounter frequencies, it is probably not based on systematic differences in visibility between sites. One potential explanation could be a crowding effect in smaller fragments in which dispersal options are highly limited. Another potential explanation could be an edge effect in mouse lemurs. Mouse lemurs have previously been found to frequently use forest edges as feeding sites (Ganzhorn 1995, Lehman et al. 2006) and to develop rather high population densities in secondary forests (Ganzhorn and Schmid 1998). These effects could potentially lead to increased population densities in rather open and disturbed forests that contain many 'artificial edges'.

Encounter rates of Microcebus danfossi were generally comparable to those of other studies on western mouse lemurs (Supplementary Material), but low compared to populations that inhabit larger protected zones like the Ankarafantsika National Park (135,000 ha). For example, Rakotondravony and Radespiel (2007) reported site-specific abundances of Microcebus spp. in the dry forest of Ankarafantsika National Park, ranging from two to 26 individuals per kilometre. The lack of such high numbers in our study may be due to negative effects of habitat degradation or habitat fragmentation on mouse lemurs in the Sofia region that may have been caused by direct forest exploitation (for construction, charcoal etc.) or by the repeated occurrence of bush fires which may also enter forests and can alter the habitat structure and the floristic composition of forests substantially (Bloesch 1999). Negative effects of fragmentation have previously been shown for other lemur species (Ganzhorn 1994, Ganzhorn et al. 2000, Lehman et al. 2006, Irwin and Raharison 2009, Irwin et al. 2010).
Alternatively, Microcebus danfossi may naturally occur in relatively low population densities. This hypothesis is supported by the observation that $M$. danfossi has relatively low abundance values when compared to other species that were studied in disturbed forest fragments in the same biogeographic region (northwestern Madagascar) with the same methodological approaches (Supplementary Material, Olivieri et al. 2005).

Potentially, two more factors could explain low encounter rates in the surveyed forest fragments: (1) Seasonal changes in visibility or activity pattern (Schmid and Kappeler 1998, Atsalis 2000, Randrianambinina et al. 2003, Rasoazanabary 2006, Lehman 2006), or (2) ecological differences between the sites causing differences in the carrying capacity of the habitats (Rakotondravony and Radespiel 2009). Seasonal effects are not very likely, since neither the encounter frequencies nor the density estimates increased or decreased significantly over the course of the year (results not shown). Potential ecological differences between the visited forest fragments, however, cannot be excluded and this aspect certainly needs further attention.

The highest encounter rates of mouse lemurs and sportive lemurs were found in the coastal site Anjajavy, one of the largest and most intact forests. Most likely, the presence of the Anjajavy Hotel in the immediate vicinity of this forest, which provides local villagers with employment, contributed to this relative intactness. The hotel may have a stabilizing effect on the financial situation of the villagers, reducing the need to exploit the natural resources of the forest. Lepilemur grewcockorum was only found in three of 11 sites. Encounter rates of $L$. grewcockorum were generally low compared to data on sportive lemurs in many other parts of Madagascar (Supplementary Material), but show similarities to the results of the study by Olivieri et al. (2005) in the same region. It has previously been shown that sportive lemurs have more difficulties coping with habitat changes such as an increasing degree of habitat fragmentation and habitat degradation than mouse lemurs (Ganzhorn 1994b, Ganzhorn et al. 2000, Olivieri et al. 2005). Sportive lemurs were previously reported to sleep in tree holes during the dry season and in tangles of vines and leaves during the rainy season (Rasoloharijaona et al. 2003, 
2008). Forest quality determines the availability of tree holes because mature forests, but not degraded forest, are more likely to harbour old and hollow trees. Thus, the long-term survival of sportive lemurs with their very fragmented and limited distribution (Craul et al. 2007) may critically depend on the availability of intact forests providing not only sufficient food and suitable substrates for locomotion (Ganzhorn 1988), but also a sufficient number of suitable shelters for daytime resting. As shown for other sportive lemurs, L. grewcockorum also suffers from a high hunting pressure (Olivieri et al. 2005). These animals are easy and defenceless prey for hunters that find their sleeping sites during the day and cut the tree down or climb it to fetch them.

The limited and fragmented distribution of Microcebus danfossi and Lepilemur grewcockorum indicate that they are much more threatened than previously thought. The IUCN Red List of Threatened Species is recognized as the most comprehensive, objective global approach for evaluating the conservation status of plant and animal species. It plays an increasingly important role in guiding conservation decisions of governments and NGOs. It has introduced a standard in defining the risk of extinction which is universally applicable to all species (IUCN 2001). Based on the latest IUCN Red List, M. danfossi and L. grewcockorum were so far categorized as 'data deficient'. Based on the results of this and a previous study (Olivieri et al. 2005), and in view of the IUCN criteria (IUCN 2001), we propose the following revision of this status: 1) Although the area between the rivers Sofia and Maevarano covers about $11,000 \mathrm{~km}^{2}$, the actual extent of occurrence of $M$. danfossi, estimated as a minimum convex polygon around all known sites of occurrence, covers only about $7,600 \mathrm{~km}^{2}$ (Table 4 , Radespiel unpubl. data). Based on this limited size, the severe degree of habitat fragmentation and the continuing decline of habitats, we propose $M$. danfossi to be categorized as Vulnerable (B1ab(iii), Table 4). 2) The actual extent of occurrence of L. grewcockorum, estimated as a minimum convex polygon around all known sites of occurrence, covers only about 1,200 $\mathrm{km}^{2}$ (Radespiel unpubl. data). Based on this small size, the severe degree of habitat fragmentation in the area, the continuing decline and disturbance of habitats, their disappearance from many sites and the severe hunting pressure on the remaining free-living populations, we propose L. grewcockorum to be categorized as Endangered (B1ab(iii), Table 4).

Based on fragment size, overall state of the forest and presence of both regional endemics, Microcebus danfossi and Lepilemur grewcockorum, Anjajavy qualifies best for intensified conservation efforts. However, given that the genetic and ecologic diversity of species cannot be preserved by protecting one population only, all remaining known populations of L. grewcockorum are recommended to receive conservation attention. These are Anjiamangirana I and Ambongabe from a previous study (Olivieri et al. 2005) and Ambarijeby and Bekofafa from this study.

\section{CONCLUSIONS}

The fragments in the Antsohihy region differed largely in the number of inventoried lemur species, fragment size, and anthropogenic disturbance. Whereas Microcebus sp. could be found in all sites, Lepilemur grewcockorum was already absent from most fragments, and can therefore be assumed to be much more sensitive to habitat changes than the much smaller mouse lemurs. Based on these newly available data on the presence and abundance of the two recently described regional endemics, the conservation status of both lemur species could be defined for the first time and reveals the urgent need for effective conservation activities in this area. Since none of the visited fragments is so far formally protected, we recommend five fragments with a high conservation potential to be included in the future conservation management of the Antsohihy region. Any protected forest that ensures the long-term survival of L. grewcockorum, will also serve to protect many more forest-dwelling species, and among these will certainly also be $M$. danfossi.

\section{ACKNOWLEDGMENTS}

We thank CAFF/CORE and the Ministry of Environment and Forest for the authorization to conduct this research. Many thanks go to V. Randrianjafy, H. Randrianizahana, F. R. Ramarolahy, and R. Harivelo for their assistance in the field, and to M. Joly-Radko, Sh. Kessler, three anonymous reviewers and the editor for very helpful comments on the manuscript. We thank R. Brüning, S. von den Berg and E. Engelke for technical assistance. BIOPAT e.V. (<www.biopat.de>) and Danfoss Deutschland provided funding for this study.

\section{REFERENCES}

Andriaholinirina, N., Fausser, J. L., Roos, C., Zinner, D., Thalmann, U., Rabarivola, C., Ravoarimanana, I., Ganzhorn, J. U., Meier, B., Hilgartner, R., Walter, L., Zaramody, A., Langer, C., Hahn, T., Zimmermann, E., Radespiel, U., Craul, M., Tomiuk, J., Tattersall, I. and Rumpler, Y. 2006. Molecular phylogeny and taxonomic revision of the sportive lemurs (Lepilemur, Primates). BMC Evolutionary Biology 6: 17. (doi:10.1186/1471-2148-6-17)

Andriantompohavana, R., Zaonarivelo, J. R., Engberg, S. E., Randriamampionona, R., Mcguire, S. M., Shore, G. D., Rakotonomenjanahary, R., Brenneman, R. A. and Louis Jr., E. E. 2006. Mouse lemurs of Northwestern Madagascar with a description of a new species at Lokobe Special Reserve. Occasional Papers of the Museum of Texas Tech University 259: 1-24.

Atsalis, S. 2000. Spatial distribution and population composition of the brown mouse lemur (Microcebus rufus) in Ranomafana National Park, Madagascar, and its implications for social organization. American Journal of Primatology 51: 61-78. doi:10.1002/(SICI)10982345(200005)51:1<61::AID-AJP5>3.0.CO;2-2)

Bloesch, U. 1999. Fire as a tool in the management of a savanna/dry forest reserve in Madagascar. Applied Vegetation Science 2: 117-124. (doi:10.2307/1478888)

Craul, M., Zimmermann, E., Rasoloharijaona, S., Randrianambinina, B. and Radespiel, U. 2007. Unexpected species diversity of Malagasy primates (Lepilemur spp.) in the same biogeographical zone: A morphological and molecular approach with the description of two new species. BMC Evolutionary Biology 7: 83. (doi:10.1186/1471-2148-7-83)

Ganzhorn, J. U. 1988. Food partitioning among Malagasy primates. Oecologia 75: $436-450$.

Ganzhorn, J. U. 1994. Lemurs as indicators for habitat change. In: Current Primatology, Vol. 1: Ecology and Evolution. B. Thierry, J. R. Anderson, J. J. Roeder and N. Herrenschmidt (eds.), pp 51-56, University Louis Pasteur, Strasbourg.

Ganzhorn, J. U. 1995. Low-level forest disturbance effects on primary production, leaf chemistry, and lemur populations. Ecology 76: 2084-2096.

Ganzhorn, J. U. and Schmid, J. 1998. Different population dynamics of Microcebus murinus in primary and secondary deciduous dry forests of Madagascar. International Journal of Primatology 19: 785-796.

Ganzhorn, J. U., Goodman, S. M., Ramanamanjato, J.-B., Ralison, J., Rakotondravony, D. and Rakotosamimanana, B. 2000. Effects of fragmentation and assessing minimum viable populations of lemurs in Madagascar. In: Isolated Vertebrate Communities in the Tropics. G. Rheinwald (ed.), pp 265-272. Bonner zoologische Monographien Edition 46, Museum Alexander Koenig, Bonn. 
TABLE 4. Evaluation of the IUCN criteria for the classification of both lemur species. ?: data not yet available.

\begin{tabular}{|c|c|c|}
\hline IUCN criterion - Criterion B - "geographic range" & M. danfossi & L. grewcockorum \\
\hline \multicolumn{3}{|c|}{ Category Endangered: 1. + at least two of a-c } \\
\hline 1. Extent of occurrence $<5000 \mathrm{~km}^{2}$ & $\sim 7,600 \mathrm{~km}^{2}-\mathrm{no}$ & $\sim 1,200 \mathrm{~km}^{2}-$ yes \\
\hline a. severely fragmented & Yes & Yes \\
\hline \multicolumn{3}{|l|}{ b. continuing decline, based on } \\
\hline (i) extent of occurrence & $?$ & $?$ \\
\hline (ii) area of occupancy & $?$ & $?$ \\
\hline (iii) area, extent and/or quality of habitat & Yes & Yes \\
\hline (iv) number of locations or subpopulations & $?$ & $?$ \\
\hline (v) number of mature individuals & $?$ & $?$ \\
\hline c. Extreme fluctuations & $?$ & $?$ \\
\hline Conclusion & not B1 & à Endangered, B1ab(iii) \\
\hline \multicolumn{3}{|c|}{ Category Vulnerable: $1 .+$ at least two of a-c } \\
\hline 1. Extent of occurrence $<20,000 \mathrm{~km}^{2}$ & $\sim 7,600 \mathrm{~km}^{2}$ - yes & \\
\hline a. Severely fragmented & Yes & \\
\hline \multicolumn{3}{|l|}{ b. Continuing decline, based on } \\
\hline (i) extent of occurrence & $?$ & \\
\hline (ii) area of occupancy & $?$ & \\
\hline (iii) area, extent and/or quality of habitat & Yes & \\
\hline (iv) number of locations or subpopulations & $?$ & \\
\hline (v) number of mature individuals & $?$ & \\
\hline c. Extreme fluctuations & $?$ & \\
\hline Conclusion & à Vulnerable, B1ab(iii) & \\
\hline
\end{tabular}

Harcourt, C. and Thornback, J. 1990. Lemurs of Madagascar and Comoros. The IUCN Red Data Book. IUCN, Gland.

Harper, G. J., Steininger, M. K., Tucker, C. J., Juhn, D. and Hawkins, F. 2007. Fifty years of deforestation and forest fragmentation in Madagascar. Environmental Conservation 34: 1-9. (doi:10.1017/S0376892907004262)

Irwin, M. T. and Raharison, J.-L. 2009. Ecosystem in decay: Factors influencing primate species extinctions in forest fragments of Tsinjoarivo, Madagascar. American Journal of Physical Anthropology 138 (suppl. 48): 155. (doi: 10.1002/ajpa.21030)

Irwin, M. T., Wright, P. C., Birkinshaw, C., Fisher B. L., Gardner, C. J., Glos, J., Goodman S. M., Loiselle, P., Rabeson, P., Raharison, J.-L., Raherilalao, M. J., Rakotondravony, D., Raselimanana, A., Ratsimbazafy, J., Sparks, J. S., Wilmé, L. and Ganzhorn, J. U. 2010. Patterns of species change in anthropogenically disturbed forests of Madagascar. Biological Conservation 143: 2351-2362. (doi:10.1016/j.biocon.2010.01.023)

IUCN 2001. IUCN Red List Categories and Criteria: Version 3.1. IUCN Species Survival Commission. IUCN, Gland, Switzerland and Cambridge, UK.

Kremen, C., Cameron, A., Moilanen, A., Phillips, S. J., Thomas, C. D., Beentje, H., Dransfield, J., Fisher, B. L., Glaw, F., Good, T. C., Harper, G. J., Hijmans, R. J., Lees, D. C., Louis, E. Jr., Nussbaum, R. A., Raxworthy, C. J., Razafimpahanana, A., Schatz, G. E., Vences, M., Vieites, D. R., Wright, P. C., and Zjhra, M. L. 2008. Aligning conservation priorities across taxa in Madagascar with high-resolution planning tools. Science 320: 222-226.

Lei, R., Engberg, S. E., Andriantompohavana, R., McGuire, S. M., Mittermeier, R. A., Zaonarivelo, J. R., Brenneman, R. A. and Louis Jr., E. E. 2008. Nocturnal lemur diversity at Masoala National Park. Special Publications of the Museum of Texas Tech University 53: 1-41.

Lehman, S. M. 2006. Effects of transect selection and seasonality on lemur density estimates in southeastern Madagascar. International Journal of Primatology 27: 1041-1057. (doi:10.1007/s10764-006-9059-7)

Lehman, S. M., Rajaonson, A. and Day, S. 2006. Edge effects and their influence on lemur density and distribution in southeast Madagascar. American Journal of Physical Anthropology 129: 232-241. (doi:10.1002/ajpa.20241)

Louis Jr., E. E., Coles, M. S., Andriantompohavana, R., Sommer, J. A., Engberg, S. E., Zaonarivelo, J. R., Mayor, M. I. and Brenneman, R. A. 2006a. Revision of the mouse lemurs (Microcebus) in eastern Madagascar. International Journal of Primatology 27: 347-389. (doi:10.1896/052.023.0103)
Louis Jr., E. E., Engberg, S., Lei, R., Geng, H., Sommer, J., Randriamampionona, R., Randriamanana, J., Zaonarivelo, J., Andriantompohavana, R., Randria, G., Prosper, Ramaromilanto, B., Rakotoarisoa, G., Rooney, A. and Brenneman, R. 2006b. Molecular and morphological analyses of the sportive lemurs (family Megaladapidae: Genus Lepilemur) reveals 11 previously unrecognized species. Special Publications of the Museum of Texas Tech University 49:1-47.

Louis Jr., E. E., Engberg, S. E., McGuire, S., McCormick, M. J., Randriamampionona, R., Ranaivoarisoa, J. F., Carolyn, A. B., Russell, A., Mittermeier, R. A. and Lei, R. 2008. Revision of the mouse lemurs, Microcebus (Primates, Lemuriformes), of northern and northwestern Madagascar with descriptions of two new species at Montagne d'Ambre National Park and Antafondro Classified Forest. Primate Conservation 23: 19-38. (doi: 10.1896/052.023.0103)

Martin, R. D. 1972. A preliminary study of the lesser mouse lemur (Microcebus murinus J. F. Miller 1777). Zeitschrift für Tierpsychologie 9 (suppl.): 43-89.

Mittermeier, R. A., Konstant, W. R. and Rylands, A. B. 2003. Lemur conservation. In: The Natural History of Madagascar. S. M. Goodman and J. P. Benstead (eds.), pp 1538-1543. The University of Chicago Press, Chicago.

Mittermeier, R. A., Ganzhorn, J. U., Konstant, W. R., Glander, K., Tattersall, I., Groves, C. P., Rylands, A. B., Hapke, A., Ratsimbazafy, J., Mayor, M. I., Louis Jr., E. E., Rumpler, Y., Schwitzer, C. and Rasoloarison, R. M. 2008. Lemur diversity in Madagascar. International Journal of Primatology 29: 1607-1656. (doi:10.1007/s10764-008-9317-y)

Mittermeier, R. A., Louis Jr., E. E., Richardson, M., Schwitzer, C., Langrand O., Rylands, A. B., Hawkins, F., Rajaobelina, S., Ratsimbazafy, J., Rasoloarison, R., Roos, C., Kappeler, P. M. and Mackinnon J. 2010. Lemurs of Madagascar. $3^{\text {rd }}$ edition. Conservation International, Arlington.

Müller, P., Velo, A., Raheliarisoa, E.-O., Zaramody, A. and Curtis, D. J. 2000. Surveys of sympatric lemurs at Anjamena, north-west Madagascar. African Journal of Ecology 38: 248-257. (doi:10.1046/j.13652028.2000.00247.x)

Myers, N., Mittermeier, R. A., Mittermeier, C. G., da Fonseca, G. A. B. and Kent, J. 2000. Biodiversity hotspots for conservation priorities. Nature 403: 853-858. 
Olivieri, G., Craul, M. \& Radespiel, U. 2005. Inventaires des lémuriens dans 15 fragments de forêt de la province de Mahajanga. Lemur News 10: 11-16.

Olivieri, G., Randrianambinina, B., Rakotondavony, D., Zimmermann E. and Radespiel, U. 2007. The ever-increasing diversity in mouse lemurs: three new species in north and northwestern Madagascar. Molecular Phylogenetics \& Evolution 43: 309-327. (doi:10.1016/j. ympev.2006.10.026)

Olivieri, G. L., Sousa, V., Chikhi, L. and Radespiel, U. 2008. From genetic diversity and structure to conservation: Genetic signature of recent population declines in three mouse lemur species (Microcebus spp.). Biological Conservation 141: 1257-1271. (doi:10.1016/j.biocon.2008.02.025)

Rabarivola, C., Zaramody, A., Fausser, J.-L., Andriaholinirina, N. and Roos, C 2006. Cytogenetic and molecular characteristics of a new species of sportive lemur from northern Madagascar. Lemur News 11: 45-49.

Radespiel, U. and Raveloson, H. 2001. Preliminary study on the lemur communities at three sites of dry deciduous forest in the Réserve Naturelle d'Ankarafantsika. Lemur News 6: 22-24.

Radespiel, U., Olivieri, G., Rasolofoson, D. W., Rakotondratsimba, G., Rakotonirainy, O., Rasoloharijaona, S., Randrianambinina, B., Ratsimbazafy, J. H., Ratelolahy, F., Randriamboavonjy, T., Rasolofoharivelo, T., Craul, M., Rakotozafy, L. and Randrianarison, R. M. 2008. Exceptional diversity of mouse lemurs (Microcebus spp.) in the Makira region with the description of one new species. American Journal of Primatology 70: 1-14. (doi:10.1002/ajp.20592)

Rakotondravony, R. \& Radespiel, U. 2007. Variation de la distribution de deux espèces de microcèbes dans le Parc National Ankarafantsika. Lemur News 12: 31-34.

Rakotondravony, R. and Radespiel, U. 2009. Varying patterns of coexistence of two mouse lemur species (Microcebus ravelobensis and $M$. murinus) in a heterogeneous landscape. American Journal of Primatology 71: 928-938. (doi:10.1002/ajp.20732)

Randrianambinina, B., Rakotondravony, D., Radespiel, U. and Zimmermann, E. 2003. Seasonal changes in general activity, body mass and reproduction of two small nocturnal primates: A comparison of the golden brown mouse lemur (Microcebus ravelobensis) in northwestern Madagascar and the brown mouse lemur (Microcebus rufus) in eastern Madagascar. Primates 44: 321-331. (doi:10.1007/s10329-0030046-8)

Rasoazanabary, E. 2006. Male and female activity patterns in Microcebus murinus during the dry season at Kirindy Forest, western Madagascar. International Journal of Primatology 27: 437-464. (doi:10.1007/s10764006-9017-4)
Rasoloarison, R. M., Goodman, S. M. and Ganzhorn, J. U. 2000. Taxonomic revision of mouse lemurs (Microcebus) in the western portions of Madagascar. International Journal of Primatology 21: 963-1019. (doi:10.1023/A:1005511129475)

Rasoloharijaona, S., Rakotosamimanana, B., Randrianambinina, B. and Zimmermann, E. 2003. Pair-specific usage of sleeping sites and their implications for social organization in a nocturnal Malagasy primate, the Milne Edwards' sportive lemur (Lepilemur edwardsi). American Journal of Physical Anthropology 122: 251-258. (doi:10.1002/ajpa.10281)

Rasoloharijaona, S., Randrianambinina, B. and Zimmermann, E. 2008. Sleeping site ecology in a rain-forest dwelling nocturnal lemur (Lepilemur mustelinus): Implications for sociality and conservation. American Journal of Primatology 70: 247-253. (doi:10.1002/ajp.20487)

Schmid, J. and Kappeler, P. M. 1994. Sympatric mouse lemurs (Microcebus spp.) in western Madagascar. Folia Primatologica 63: 162-170. (doi:10.1159/000156812)

Schmid, J. and Kappeler, P. M. 1998. Fluctuating sexual dimorphism and differential hibernation by sex in a primate, the gray mouse lemur (Microcebus murinus). Behavioral Ecology and Sociobiology 43: 125-132.

Weisrock, D. W., Rasoloarison, R. M., Fiorentino, L., Ralison, J. M., Goodman, S. M., Kappeler, P. M. and Yoder, A. D. 2010. Delimiting species without nuclear monophyly in Madagascar's mouse lemurs. PLOS ONE 5: e9883. (doi:10.1371/journal.pone.0009883)

Yoder, A. D., Rasoloarison, R. M., Goodman, S. M., Irwin, J. A., Atsalis, S. Ravosa, M. J. and Ganzhorn, J. U. 2000. Remarkable species diversity of Malagasy mouse lemurs (Primates, Microcebus). Proceedings of the National Academy of Sciences 97: 11325-11330.

Zimmermann, E., Cepok, S., Rakotoarison, N., Zietemann, V. and Radespiel, U. 1998. Sympatric mouse lemurs in northwest Madagascar: A new rufous mouse lemur species (Microcebus ravelobensis). Folia Primatologica 69: 106-114. (doi:10.1159/000021571)

\section{SUPPLEMENTARY MATERIAL.}

AVAILABLE ONLINE ONLY.

S1: Summary of previously published encounter frequencies and population densities of Microcebus spp. and Lepilemur spp. in western and eastern Madagascar, respectively. Forest sizes were added whenever they were available from the literature. (?): Taxon was not confirmed with molecular methods until now, ?: Forest size not mentioned. 